Int. J. Electrochem. Sci., 12 (2017) $9896-9906$

\title{
$\mathrm{Li}_{4} \mathrm{Ti}_{5} \mathrm{O}_{12}$ Coating Layer as $\mathrm{Li}^{+}$Conductor and Cycle Stabilizer for $\mathrm{SnO}_{2}$ Anode
}

\author{
Gong Shiding, Zhang Yaoyao, Sun Fang, Zeng Tianbiao, Hu Xuebu*
}

College of Chemistry and Chemical Engineering, Chongqing University of Technology, Chongqing 400054, China

*E-mail: $\underline{x u e b u @ c q u t . e d u . c n}$

doi: $10.20964 / 2017.10 .100$

Received: 14 April 2017 / Accepted: 17 May 2017 / Published: 12 September 2017

$\mathrm{Li}_{4} \mathrm{Ti}_{5} \mathrm{O}_{12}$ as $\mathrm{Li}^{+}$conductor and cycle stabilizer was coated successfully on mesoporous $\mathrm{SnO}_{2}$ spheres $\left(\mathrm{M}-\mathrm{SnO}_{2}\right)$ via in-situ synthesis. The structure and morphology of as-prepared samples were characterized by X-ray diffraction (XRD), scanning electron microscopy (SEM) and transmission electron microscopy (TEM). The results indicated that the $\mathrm{SnO}_{2}$ spheres were coated fully by $\mathrm{Li}_{4} \mathrm{Ti}_{5} \mathrm{O}_{12}$ layer, and the $\mathrm{Li}_{4} \mathrm{Ti}_{5} \mathrm{O}_{12}$ layer did not change the structure or morphology of $\mathrm{M}-\mathrm{SnO}_{2}$. Electrochemical impedance spectra (EIS) and charge/discharge tests showed that the outer $\mathrm{Li}_{4} \mathrm{Ti}_{5} \mathrm{O}_{12}$ coating layer enhanced $\mathrm{Li}^{+}$diffusion in $\mathrm{SnO}_{2}$ anode. The $\mathrm{Li}^{+}$diffusion coefficient for $\mathrm{S}-1$ and $\mathrm{S}-2$ reached to $9.87 \times 10^{-13} \mathrm{~cm}^{2} \mathrm{~s}^{-1}$ and $1.82 \times 10^{-12} \mathrm{~cm}^{2} \mathrm{~s}^{-1}$, while the value of $\mathrm{M}-\mathrm{SnO}_{2}$ was only $6.36 \times 10^{-13} \mathrm{~cm}^{2} \mathrm{~s}^{-1}$. The cycle stability and rate cycle property of $\mathrm{SnO}_{2}$-based anode were improved significantly due to promotional role of $\mathrm{Li}_{4} \mathrm{Ti}_{5} \mathrm{O}_{12}$ coating layer.

Keywords: $\mathrm{SnO}_{2}, \mathrm{Li}_{4} \mathrm{Ti}_{5} \mathrm{O}_{12}, \mathrm{Li}^{+}$conductor, cycle stabilizer, $\mathrm{Li}^{+}$diffusion coefficient

\section{FULL TEXT}

(C) 2017 The Authors. Published by ESG (www.electrochemsci.org). This article is an open access article distributed under the terms and conditions of the Creative Commons Attribution license (http://creativecommons.org/licenses/by/4.0/). 